\title{
Ion microprobe (SHRIMP) dates complex granulite from Santa Catarina, southern Brazil
}

\author{
LÉO A. HARTMANN ${ }^{1}$, JOÃO O. S. SANTOS ${ }^{2}$, NEAL J. McNAUGHTON ${ }^{3}$, \\ MARCOS A. Z. VASCONCELLOS ${ }^{4}$ and LUIZ C. DASILVA ${ }^{2}$ \\ ${ }^{1}$ Instituto de Geociências, Universidade Federal do Rio Grande do Sul, \\ 91500-000 Porto Alegre, RS, Brazil \\ ${ }^{2}$ Geological Survey of Brazil (CPRM), Porto Alegre, RS, Brazil \\ ${ }^{3}$ Centre for Strategic Mineral Deposits, University of Western Australia, \\ Nedlands 6907, Western Australia \\ ${ }^{4}$ Instituto de Física, Universidade Federal do Rio Grande do Sul, \\ 91500-000 Porto Alegre, RS, Brazil
}

Manuscript received on January 24, 2000; accepted for publication on May 10, 2000; contributed by LÉO A. HARTMANN*

\begin{abstract}
Complex polymetamorphic granulites have been dated in the Santa Catarina granulite complex of southern Brazil through SHRIMP study of zircon. This complex is dominated by intermediate-acid plutonic rocks and contains small volumes of mafic and ultramafic rocks, and minor quartzite and banded iron formation. Porphyroblasts of orthopyroxene, clinopyroxene and plagioclase in mafic and acid rocks are interpreted as magmatic remnants in a volumetrically dominant granoblastic aggregate $\left(\mathrm{M}_{1}\right)$ of the same minerals and hornblende. Hornblende formed during a later $\mathrm{M}_{2}$ metamorphic event constitutes rims around pyroxene, but the hornblende is also rimmed by granoblastic simplectites of orthopyroxene, clinopyroxene, hornblende and plagioclase in a second granulite facies event $\left(\mathrm{M}_{3}\right)$. Chlorite and epidote occur in shear zones $\left(\mathrm{M}_{4}\right)$. This granulite terrain is part of a Neoproterozoic craton, because it was little affected by the Brasiliano Cycle. The two granulite-facies events $\left(\mathrm{M}_{1}\right.$ and $\left.\mathrm{M}_{3}\right)$ are dated by $\mathrm{U} / \mathrm{Pb}$ zircon SHRIMP at about 2.68 and $2.17 \mathrm{Ga}$, while the magmatic protoliths formed at about $2.72 \mathrm{Ga}$. The amphibolite facies event $\left(\mathrm{M}_{2}\right)$ probably occurred close to the $2.17 \mathrm{Ga}$ granulitic metamorphism.
\end{abstract}

Key words: granulites, SHRIMP, U/Pb geochronology, Santa Catarina granulite complex, Brazil, symplectites, zircon.

\section{INTRODUCTION}

Precise dating of the initial magmatic crystallization and subsequent metamorphism of granulite facies rocks is a difficult task, because the intense deformation and extensive geochemical reorganization of such rocks tend to partially reset and blurr isotopic

\footnotetext{
* Member of the Academia Brasileira de Ciências Correspondence to: Léo A. Hartmann

E-mail: afraneo@if.ufrgs.br
}

systematics. The high resistance of zircon to modifications by geological processes has made it a very useful mineral in geochronology. U/Pb dating of zircon has led to a considerable advance in our understanding of the evolution of complex high-grade terrains (e.g. Heaman \& Parrish 1991). Nevertheless, the partial recrystallization, or new growth of some of these zircon crystals during metamorphism requires detailed backscattered electron (BSE) and 
cathodoluminescence (CL) studies of the internal structure of the crystals (e.g. Hanchar \& Miller 1993, Vavra et al. 1999, Remus et al. 1999, Remus et al. 2000a, b, Silva et al. 1999, Silva et al. 2000, Hartmann et al. 2000) in order to identify the different growth events preserved in the zircon crystals. The use of the high spatial resolution $(30 \mathrm{~mm})$ capability of the sensitive high-mass resolution ion microprobe (SHRIMP), as demonstrated by Friend and Kinny (1995) and Hartmann et al. (1999a), may be necessary to reach geologically meaningful results from zircon crystals from high grade terrains.

The complex internal structures of granulite facies zircon crystals in the Santa Catarina granulite complex of southern Brazil provide an opportunity to test the capability of these techniques to unravel the evolution of continental crust, in a region composed of complex granulites. The presence of three generations of ortho- and clinopyroxenes in one rock highlight even further the importance of such investigation. Previous geochronology results for rocks from the Santa Catarina complex yielded variable results for metamorphism and magmatism from Archean to Paleoproterozoic (Basei et al. 1998) and this requires clarification in the context of the current study. The precise timing of events is also of significance for the establishment of the correct orogenic succession and the reconstruction of supercontinents in this southwestern portion of Gondwana. The objective of this investigation is to unravel the isotopic memory of zircons of a trondhjemite from the Santa Catarina granulite complex.

\section{GEOLOGICAL SETTING}

Brazil has extensive granulite terrains, comparable to Precambrian regions of other continents (Almeida $\&$ Hasui 1984). Brazilian granulites are mostly of the low-pressure type (4-6 kb), as in the Amazon and Bahia (Wernick \& Almeida 1979, Iyer et al. 1987). One of the deepest crustal sections in Brazil is in Rio Grande do Sul (Hartmann 1998, Campos Neto \& Caby 1999) and extends across the border into Uruguay. The granulites investigated in this study (Fig. 1) occur in the state of Santa Catarina and extend to northern Paraná state as remnant blocks in Neoproterozoic granitic-gneissic terrains (Hartmann 1988, Basei et al. 1998, Fornari 1998). These Santa Catarina granulite complex rocks occur along the coast (e.g. Barra Velha) and $60 \mathrm{~km}$ inland, where they are covered by the sedimentary and volcanic rocks of the Paraná Basin. The granulites are poorly exposed along the coast but are well exposed $30 \mathrm{~km}$ inland in the Luís Alves mountains ( 500 $\mathrm{m}$ high). Thick forest cover minimizes outcrops in the mountains, but fresh samples may be obtained along creeks and from abundant boulders. A quarry was selected for sampling, because the structure of the rocks is well exposed. The analysed rock was collected in the Luís Alves quarry, located on the northeast side of the Itajaí-Luís Alves highway, 18 km northwest of the Br-101 highway bridge over the Itajaí River. In the quarry, the sample was collected $2 \mathrm{~m}$ above the ground and $5.5 \mathrm{~m}$ from the northwest end of the cliff.

The granulite complex is covered in the south by the weakly deformed late Neoproterozoic sedimentary and volcanic rocks of the Itajaí basin which is a foreland basin of the Brasiliano Cycle (Gresse et al. 1996). A few Neoproterozoic peralkaline granites also intrude the northern part of the granulite complex in Santa Catarina state. Within the complex, present topography is mostly controlled by EW and NS, brittle to brittle-ductile fault zones along valleys (Hartmann et al. 1979a).

Although rocks of the granulite-facies predominate, some areas contain amphibolite facies rocks. The relationship between the two metamorphic events is complex, but the generation of hornblende seems in general to be younger than the main metamorphic event which generated orthopyroxenes and clinopyroxenes (Basei et al. 1998). Bimodal basicacid rocks are common, but intermediate compositions predominate. It is unclear whether magma mixing and mingling were operating at the time of formation of the rocks, or whether later tectonic mixing was a major process in the generation of the abundant intermediate granulites (Fornari 1998). 


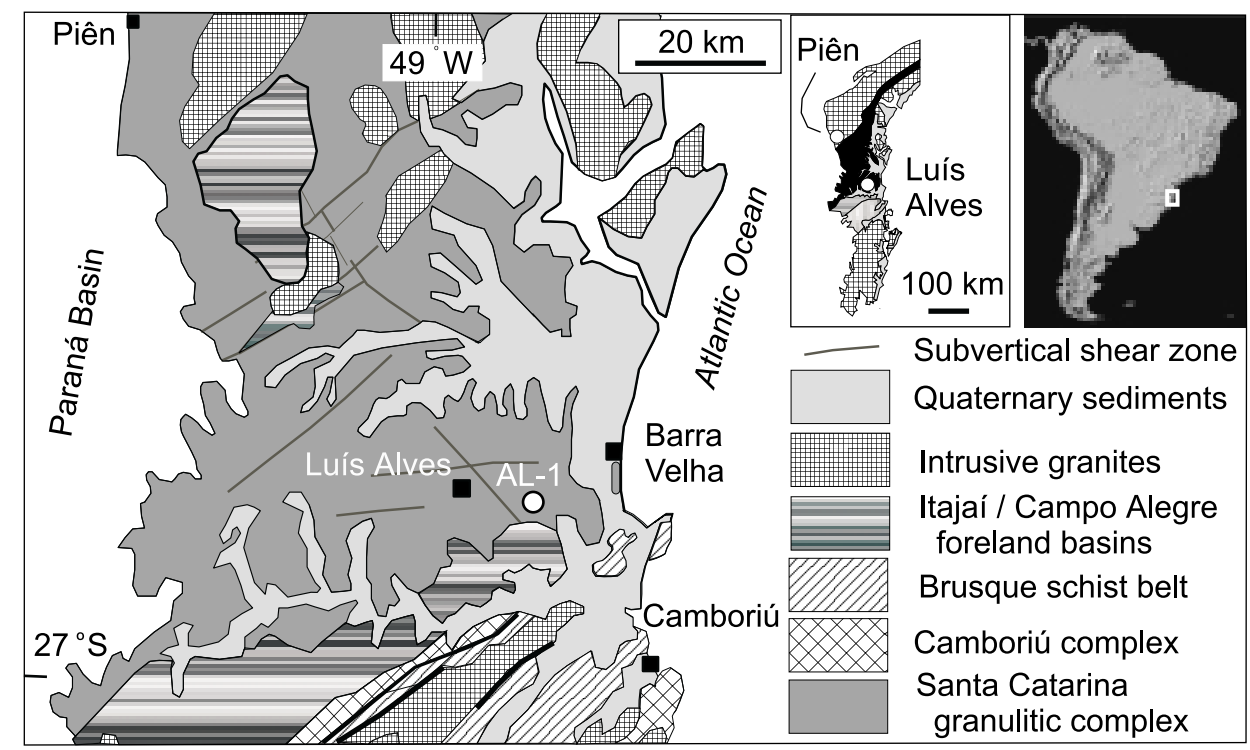

Fig. 1 - Geological map of the Santa Catarina granulitic complex, showing location of dated sample, AL-1. South of the map area, the geology is dominated by the Paleoproterozoic Camboriú graniticgneissic complex and by the Neoproterozoic Florianópolis K-granitic batholith. Insets show location of study area in South America and regional geology.

Also occurring in the complex are tens of boudinaged pyroxenite bodies 100 to $1000 \mathrm{~m}$ in length and about $3: 1$ length:width ratios, probably originated from accumulation of clinopyroxenes in mafic magma chambers (Figueiredo et al. 1996, Fornari 1998), later deformed during granulite facies conditions. Peridotites are known only in the northern extension of the granulite complex in Paraná state (Girardi \& Ulbrich 1980). One 10-km long body of K-syenite occurs near the coast, and a $20 \mathrm{~km}$ large charnockite body occurs in the Pomerode region (Fornari 1998). Supracrustal rocks are subordinate and consist mostly of orthopyroxene-bearing quartzites and iron formations.

A dominant plutonic origin is preferred for the granulites (Figueiredo et al. 1996), possibly in two suites - mafic-ultramafic and intermediate-acid (Fornari 1998). The tectonic environment of crustal accretion was probably similar to an island arc, as indicated by whole-rock geochemistry of the intermediate-acid suite (Basei et al. 1998). The granulitic gneisses have a diffuse to well-developed,
NE-oriented, subvertical foliation, which bends northwestward in the northern part of the area (Fornari 1998). The complex structure of the granulite complex and poor exposure have precluded the determination of the precise sequence of the magmatic and sedimentary/volcanic protolithic units. Hence they provide a good test of the usefullness of zircon geochronology to resolve a specific tectonic problem.

\section{PREVIOUS GEOCHRONOLOGY}

The granulite complex was little affected by the Neoproterozoic Brasiliano Cycle orogenic events, because only a few K-Ar mineral ages of about 600 Ma (Basei et al. 1998) are present mostly along shear zones. However, tectonic stabilization had been attained by $1.8 \mathrm{Ga}$, as shown by some $\mathrm{K}-\mathrm{Ar}$ mineral ages (Basei et al. 1998). The Archaean/Paleoproterozoic history of the complex terrain presumably involved five steps, identified by several isotopic techniques ( $\mathrm{Sm}-\mathrm{Nd} \mathrm{T}_{\mathrm{DM}}, \mathrm{Rb}$ $\mathrm{Sr}$ whole rock isochrons, $\mathrm{Pb} / \mathrm{Pb}, \mathrm{Sm}-\mathrm{Nd}$ mineral 
isochrons and conventional $\mathrm{U} / \mathrm{Pb}$ zircon ages), according to Basei et al. (1998). Two events of accretion of juvenile mantle material presumably occurred at $2.7-2.8 \mathrm{Ga}$ and $2.3-2.4 \mathrm{Ga}$, igneous rock intrusion at $2.6 \mathrm{Ga}$, granulite facies metamorphism at $2.3 \mathrm{Ga}$ and amphibolite facies metamorphism at $2.0 \mathrm{Ga}$.

The use of different isotopic dating techniques in several rocks renders the comparison of the results difficult. A $2.2 \mathrm{Ga} \mathrm{Sm} / \mathrm{Nd}$ mineral isochron age from diopside, hornblende, titanite and allanite of a syenite gneiss (Hartmann et al. 1999b) and several other ages of $2.2 \mathrm{Ga}$ from other isotopic systems were interpreted as the time of granulite facies metamorphism. $\mathrm{Sm} / \mathrm{Nd} \mathrm{T}_{\mathrm{DM}}(\sim 2.6-2.7 \mathrm{Ga})$ and $\mathrm{Rb} / \mathrm{Sr}$ geochronology point to juvenile accretion and possibly granulite facies metamorphism of the protoliths in the late Archaean (Basei et al. 1998). The ages obtained between $2.7-2.8 \mathrm{Ga}$ and 2.2 Ga may correspond to partial resetting of isotopic components during the Paleoproterozoic event, which requires further testing. SHRIMP U/Pb zircon spot dating helps unravel part of this complex geologic evolution, as shown below.

\section{METHODOLOGY}

Field mapping was undertaken in 1977, in the Luís Alves region, at the 1:50,000 scale, by undergraduate students of Universidade do Vale do Rio dos Sinos and supervised by the first author. Additional field investigations were undertaken by the authors and other researchers (Hartmann et al. 1979b, Girardi \& Ulbrich 1980, Moreira \& Marimon 1980, Silva 1987, Kaul \& Teixeira 1982, Hartmann 1988, Figueiredo et al. 1996, Basei et al. 1998, Fornari 1998).

Zircon crystals from the dated sample, AL-1, were separated at the University of Western Australia laboratories by grinding crushed fragments in a ring mill to pass through a 60\# nylon disposable sieve, washing and decanting fines with water. The crushed samples were passed through heavy liquid (LST and di-iodomethane) and magnetic sepa- ration before hand-picking using a binocular microscope. Selected crystals were mounted in an epoxy disc with chips of the CZ3 zircon standard (564 $\mathrm{Ma}$ ), ground and polished until nearly half of each crystal was removed. The zircon crystals were microphotographed in transmitted and reflected light, and imaged for their internal morphology using an environmental scanning electron microscope (i.e. back-scattered electron and charging contrast). The mount was then cleaned and gold coated in preparation for SHRIMP analyses.

BSE and CL images were made of rock texture and zircon morphology in a thin section of sample AL-1 with a CAMECA SX-50 electron microprobe installed at "Centro de Estudos em Petrologia e Geoquímica / IG / UFRGS", in Porto Alegre, Brazil. WDS quantitative chemical analyses of orthopyroxene, clinopyroxene and hornblende followed the methodology of Hartmann et al. (1997). Charging contrast images (CCI) were made in a JEOL superprobe at UWA; these images are made in very low vacuum conditions and are overall similar to CL images.

The isotopic composition of the zircons was determined using a SHRIMP II instrument installed at Curtin University, using methods published by Compston et al. (1992), Smith et al. (1998) and De Laeter and Kennedy (1998). Circular to oval areas of $20-30 \mu \mathrm{m}$ were analysed from homogeneous areas chosen within zircon crystals, together with replicate analyses of the CZ3 standard in the same epoxy mount. Correction for common $\mathrm{Pb}$ was made using the measured ${ }^{204} \mathrm{~Pb}$ and the $\mathrm{Pb}$ isotopic composition for Broken Hill galena. The level of common $\mathrm{Pb}$ is similar to that observed in the CZ3 standard and is considered to be largely from the gold coat. The uncertainty in all reported ages is at $95 \%$ confidence level, unless otherwise stated.

\section{GEOCHRONOLOGY}

Sample AL-1 is a trondhjemite, representative of the acid lithologies of the granulite complex. Basic rocks also occur in the quarry. See Appendix 1 for 
sample description.

Three generations of two-pyroxene formation are observed. The first generation is remnant magmatic (M), strongly exsolved. The second generation is metamorphic $\left(\mathrm{M}_{1}\right)$, and corresponds to the strong granulite facies event observed in the complex. The metamorphic event $\mathrm{M}_{2}$ is the formation of rims of hornblende around the pyroxenes, while a most significant texture is the presence of simplectites of two-pyroxenes $\left(\mathrm{M}_{3}\right)$ around the hornblendes (Appendix 2).

Zircon crystals in sample AL-1 are mostly rounded but some have prism and pyramid forms in thin section; they are pinkish brown, and occur mostly included in plagioclase but also in orthopyroxene. The observation of 150 crystals in BSE and CCI showed them to be little metamict with variable intensity of fracturing. Intensely metamict portions of crystals are identified because they are dark in both BSE and CCI images. The least fractured crystals were chosen for the SHRIMP analyses. All crystals exhibit rounded edges, even the elongated, nearly euhedral crystals (Fig. 2). Fractures are still present in the medium gray magmatic portions, but are sealed in the portions of the fractures which are bright (in BSE). This alteration process is similar to the crystals described by Hartmann et al. (1997). Some crystals have a soccer-ball shape (Fig. 2a), typical of granulite facies zircons (e.g. Vavra et al. 1999, Hartmann et al. 1999a). Mineral inclusions are rare and when present are small in the zircon crystals.

Fourteen $\mathrm{U} / \mathrm{Th} / \mathrm{Pb}$ isotopic spot determinations on 13 zircon crystals from sample AL-1 (Table I, Fig. 3) yield a spread of $\mathrm{Pb}^{207} / \mathrm{Pb}^{206}$ ages between $\sim 2.7$ and $\sim 2.2 \mathrm{Ga}$, although most ages are Archaean. High $\mathrm{U}$ contents in many of the zircon crystals probably caused incipient metamictization of the zircons, not observed in BSE/CL/CCI images, and consequently these are more prone to later lead loss. These ages between Archean and Paleoproterozoic are independent of the internal structure of the zircon under the analysed spot, except for the $\sim 2.2$ Ga results, which were obtained in the rim of a

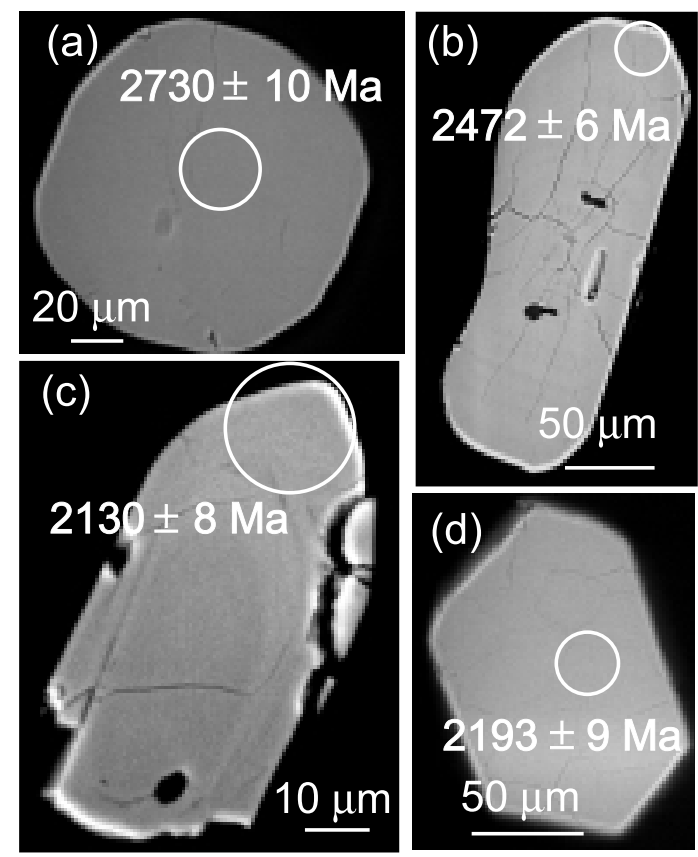

Fig. 2 - BSE images of zircon crystals from dated granulite, sample AL-1; SHRIMP spots indicated as white circles; ages of spots shown. (a) Soccer-ball $M_{1}$ zircon crystal, formed during Archean granulite facies event. (b) Rounded, elongated crystal; age is interpreted as lead loss due to a younger event (2.2 Ga?). (c) $M_{2}+M_{3}$ metamorphic events dated on rim and (d) core of subhedral crystal, interpreted as corresponding to amphibolite and recurrent granulite facies.

crystal with distinctive core. This indicates the presence of very complex internal structures, because the investigation did not allow the clear identification of the geological events on the BSE/CL images before the SHRIMP dating.

The age of $2716 \pm 17 \mathrm{Ma}$ is considered the minimum age of the magmatic crystallization of the zircons. The age of the metamorphic events can only be estimated, because of the small number of sputtered SHRIMP analytical spots.The youngest age $(2168 \pm 18 \mathrm{Ma})$ is considered the time of $\mathrm{M}_{3}$ high-grade granulite facies metamorphism, because it was obtained on rims of zircon crystals. The spots located between 2.5 and $2.7 \mathrm{Ga}$ are interpreted as due to partial resetting of magmatic and $\mathrm{M}_{1}$ crystals 


\section{TABLE I}

SHRIMP zircon isotopic data of Santa Catarina granulite, sample AL-1.

\begin{tabular}{|c|c|c|c|c|c|c|c|c|c|c|c|}
\hline Spot & $\begin{array}{r}\mathrm{U} \\
\mathrm{ppm}\end{array}$ & $\begin{array}{r}\text { Th } \\
\text { ppm }\end{array}$ & $\begin{array}{l}204 / \\
206\end{array}$ & $\begin{array}{c}4 \mathrm{f} 206 \\
(\%)\end{array}$ & $\begin{array}{l}{ }^{207} \mathrm{~Pb} / \\
{ }^{206} \mathrm{~Pb}\end{array}$ & $\begin{array}{l}{ }^{208} \mathrm{~Pb} / \\
{ }^{206} \mathrm{~Pb}\end{array}$ & $\begin{array}{c}{ }^{206} \mathrm{~Pb} / \\
{ }^{238} \mathrm{U}\end{array}$ & $\begin{array}{c}{ }^{207} \mathrm{~Pb} / \\
{ }^{235} \mathrm{U}\end{array}$ & $\begin{array}{l}{ }^{208} \mathrm{~Pb} / \\
{ }^{232} \mathrm{Th}\end{array}$ & Age & $\begin{array}{c}\text { Conc. } \\
\%\end{array}$ \\
\hline b. $1-1$ & 682 & 124 & 0.00016 & 0.248 & $0.1373 \pm 7$ & $0.0520 \pm 11$ & $0.392 \pm 6$ & $7.42 \pm 13$ & $0.1120 \pm 30$ & $2193 \pm 9$ & 97 \\
\hline b. $10-1$ & 294 & 128 & 0.00016 & 0.039 & $0.1890 \pm 9$ & $0.1260 \pm 12$ & $0.519 \pm 9$ & $13.52 \pm 24$ & $0.1501 \pm 30$ & $2733 \pm 8$ & 99 \\
\hline b. $11-1$ & 663 & 232 & 0.00016 & 0.010 & $0.1825 \pm 6$ & $0.0982 \pm 7$ & $0.521 \pm 8$ & $13.12 \pm 22$ & $0.1460 \pm 26$ & $2676 \pm 5$ & 101 \\
\hline b. $13-1$ & 428 & 8 & 0.00002 & 0.217 & $0.1760 \pm 8$ & $0.0044 \pm 11$ & $0.487 \pm 8$ & $11.82 \pm 21$ & $0.1140 \pm 278$ & $2616 \pm 8$ & 98 \\
\hline b. $14-1$ & 947 & 21 & 0.00001 & 0.132 & $0.1615 \pm 5$ & $0.0044 \pm 6$ & $0.458 \pm 7$ & $10.20 \pm 17$ & $0.0911 \pm 117$ & $2472 \pm 6$ & 98 \\
\hline b. $2-1$ & 1116 & 46 & 0.00014 & 0.007 & $0.1886 \pm 11$ & $0.0104 \pm 9$ & $0.444 \pm 7$ & $11.54 \pm 21$ & $0.1131 \pm 101$ & $2730 \pm 10$ & 87 \\
\hline b. $3-1$ & 360 & 92 & 0.00008 & 0.275 & $0.1857 \pm 11$ & $0.0710 \pm 15$ & $0.481 \pm 8$ & $12.31 \pm 23$ & $0.1334 \pm 37$ & $2704 \pm 9$ & 94 \\
\hline b. $4-1$ & 888 & 75 & 0.00000 & 0.074 & $0.1830 \pm 5$ & $0.0241 \pm 5$ & $0.503 \pm 8$ & $12.69 \pm 21$ & $0.1431 \pm 36$ & $2680 \pm 4$ & 98 \\
\hline b. $5-1$ & 151 & 124 & 0.00017 & 0.380 & $0.1884 \pm 36$ & $0.2151 \pm 72$ & $0.433 \pm 9$ & $11.25 \pm 33$ & $0.1130 \pm 46$ & $2728 \pm 31$ & 85 \\
\hline b. $6-1$ & 741 & 399 & 0.00005 & 0.074 & $0.1865 \pm 9$ & $0.1436 \pm 12$ & $0.473 \pm 8$ & $12.16 \pm 21$ & $0.1260 \pm 24$ & $2712 \pm 8$ & 92 \\
\hline b. $7-1$ & 318 & 64 & 0.00066 & 1.057 & $0.1802 \pm 21$ & $0.0477 \pm 39$ & $0.493 \pm 9$ & $12.25 \pm 27$ & $0.1167 \pm 99$ & $2655 \pm 19$ & 97 \\
\hline b. $8-1$ & 1135 & 361 & 0.00013 & 0.212 & $0.1324 \pm 6$ & $0.0712 \pm 9$ & $0.297 \pm 5$ & $5.41 \pm 9$ & $0.0664 \pm 14$ & $2130 \pm 8$ & 79 \\
\hline b.9-1 & 1421 & 150 & 0.00005 & 0.086 & $0.1728 \pm 4$ & $0.0268 \pm 4$ & $0.483 \pm 8$ & $11.50 \pm 19$ & $0.1226 \pm 27$ & $2585 \pm 4$ & 98 \\
\hline b.9-2 & 1398 & 48 & 0.00005 & 0.087 & $0.1754 \pm 4$ & $0.0083 \pm 4$ & $0.490 \pm 8$ & $11.84 \pm 19$ & $0.1174 \pm 62$ & $2610 \pm 4$ & 98 \\
\hline
\end{tabular}

Notes: Age $={ }^{207} \mathrm{~Pb} /{ }^{206} \mathrm{~Pb}$ age

$4 \mathrm{f} 206=\left(\right.$ common $\left.{ }^{206} \mathrm{~Pb}\right) /\left(\right.$ total measured $\left.{ }^{206} \mathrm{~Pb}\right)$, based on measured ${ }^{204} \mathrm{~Pb}$ and on the Broken Hill $\mathrm{Pb}$ composition.

\%conc. = percentage of concordance, as $100\left\{\mathrm{t}\left[{ }^{206} \mathrm{~Pb}^{*} /{ }^{238} \mathrm{U}\right] / \mathrm{t}\left[{ }^{207} \mathrm{~Pb}^{*} / 206 \mathrm{~Pb}^{*}\right]\right\}$.

$\mathrm{Pb}$ isotope ratios are for radiogenic components only.

Concurrent analyses calibrated to the cz3 standard, with $1 \sigma$ scatter.

during $\mathrm{M}_{3}$ metamorphism. Many spots show recent lead loss, presumably caused by weathering. The preservation of magmatic ages in the zircons from this polydeformed trondhjemite reinforces the observation of the resilient nature of zircon (e.g. Hartmann et al. 1999a).

The $\mathrm{M}_{1}$ granulite facies event is interpreted as having occurred about $2.67 \mathrm{Ga}$, while the $\mathrm{M}_{3}$ orthopyroxene crystallization probably occurred near $2.17 \mathrm{Ga}$. The timing of hornblende crystallization cannot be established from the data. The age of the $\mathrm{M}_{1}$ event is well established, because metamorphic ovate (soccer-ball) crystals were dated, but the significance of the $2.17 \mathrm{Ga}$ age is open to evaluation. Interpretation is not straightforward, because of the complex field geology and microstructure of the granulites and their zircon crystals, but this age is consistent with the $2.2 \mathrm{Ga} \mathrm{Sm} / \mathrm{Nd}$ dating of amphibolite facies minerals by Hartmann et al. (1999b). The analytical spot at $2478 \pm 5 \mathrm{Ma}$ is interpreted as partial resetting; according to this interpretation, the number has no geological meaning. But $2478 \pm 5 \mathrm{Ma}$ may actually correspond to a metamorphic event; additional work is required. Alternative geochronologic interpretations could be considered, particularly for the age of the amphibolite facies event, which is the age of $\mathrm{M}_{2}$ hornblende crystallization, but we interpret the two granulite facies events as about 2.67 and $2.17 \mathrm{Ga}$.

An alternative interpretation of the data places the magmatism and the granulite facies metamorphism $\mathrm{M}_{1}$ near $2.7 \mathrm{Ga}$, and considers progressive lead loss along a concordia from $2.7 \mathrm{Ga}$ towards about $2.0 \mathrm{Ga}$. The second granulite facies event $\left(\mathrm{M}_{3}\right)$ occurred at a younger age, according to this interpretation. Additional work is necessary to clarify these relationships, particularly the absolute age of $\left(\mathrm{M}_{2}\right)$ hornblende and $\mathrm{M}_{3}$ orthopyroxene crystallization.

Zircon $\mathrm{Th} / \mathrm{U}$ ratios are about 0.4 in the spots interpreted as magmatic (Fig. 4), but are near 0.02 in the metamorphic $M_{1}$ spots. The two spots indicating the age of ca. 2.1 Ga have ratios about 0.3 , similar to the ratios determined by Basei et al. 


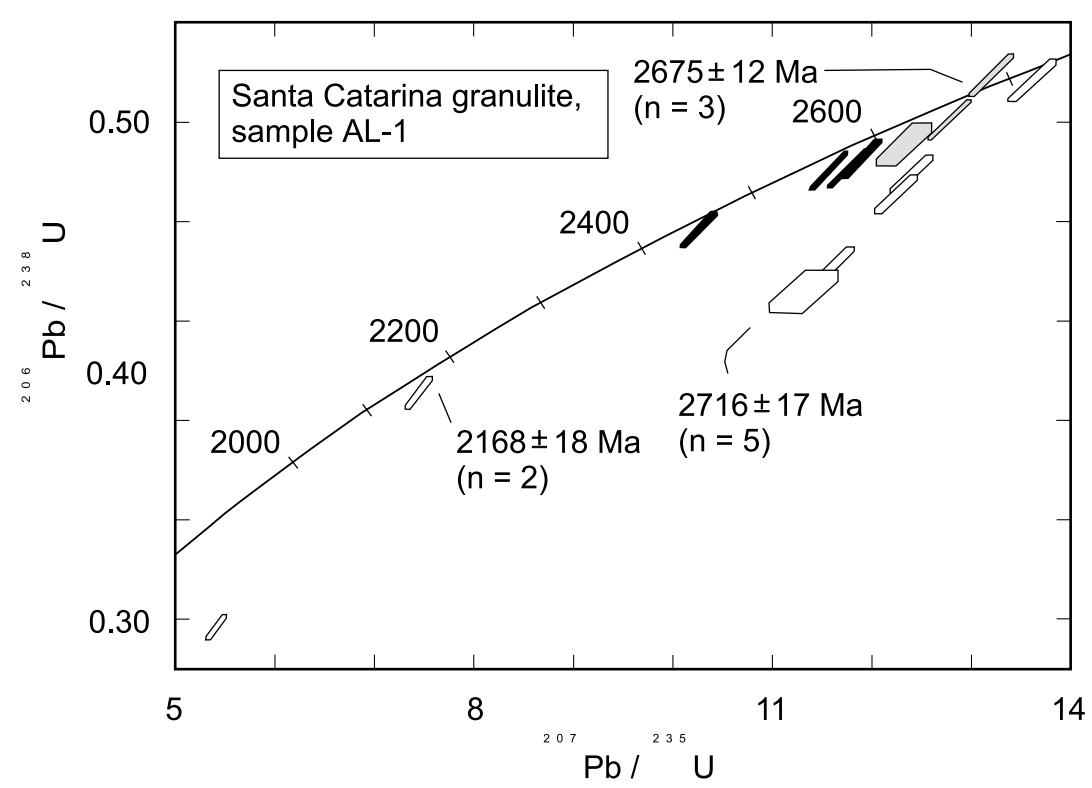

Fig. 3 - Concordia diagram of granulite, sample AL-1. Interpretation of magmatism (Archaean), $M_{1}$ granulite facies (Archaean) and $M_{2}+M_{3}$ amphibolite + recurrent granulite facies (Paleoproterozic). Analytical spots close to 2.58 and $2.48 \mathrm{Ga}$ are interpreted as lead loss during the Paleoproterozoic event. Many spots indicate modern lead loss, because they align to $0 \mathrm{Ma}$. Oldest blank spots are interpreted as magmatic about $2716 \mathrm{Ma}$; youngest blank spots are interpreted as metamorphic $M_{3}$ about 2168 Ma; shaded spots are interpreted as metamorphic $M_{1}$ about 2675 Ma; black spots are interpreted as due to partial resetting.

(1998). The ratios near 0.3 may be due to different fluid compositions or physical conditions during this event. $\mathrm{Th} / \mathrm{U}$ ratios of about 0.4 are considered typical of magmatic zircons in granitic rocks, while low ratios about 0.02 or less are considered characteristic of metamorphic zircons (Corfu 1987, Barrie \& Krogh 1996, Rubatto et al. 1998, Silva et al. 1999, Vavra et al. 1999). The Th/U ratios, in association with the zircon structure in BSE images and the SHRIMP ages, support the interpretation of the geological significance of the isotopic results presented in this paper.

In the light of SHRIMP U/Pb zircon isotopic studies in other granulite terrains (Friend \& Kinny 1995, Hartmann et al. 1999a), we interpret the spread of spots between the Archaean and Paleoproterozoic as due to partial resetting of the isotopic system during the youngest event. Magmatic zircons of
Archean age were, by this interpretation, metamorphosed during three events - granulite facies $\mathrm{M}_{1}$, amphibolite facies $\mathrm{M}_{2}$ and granulite facies $\mathrm{M}_{3}$, over a time period of about 500 million years from the $\mathrm{Ar}$ chaean to the Paleoproterozoic. No events younger than about $2.2 \mathrm{Ga}$ are registered in the zircons dated. Only K-Ar ages about $1.9 \mathrm{Ga}$ were obtained in a few samples of the complex (Basei et al. 1998). The granulite complex became a stable craton after $1.9 \mathrm{Ga}$, and remained as a largely undeformed block during the Neoproterozoic Brasiliano Cycle orogenies, and thus formed the Luís Alves craton (Kaul \& Teixeira 1982).

\section{ACKNOWLEDGEMENTS}

SHRIMP mount preparations and SEM imaging were undertaken at UWA: Marion Dahl and Brendan Griffin are acknowledged for the former and latter, 


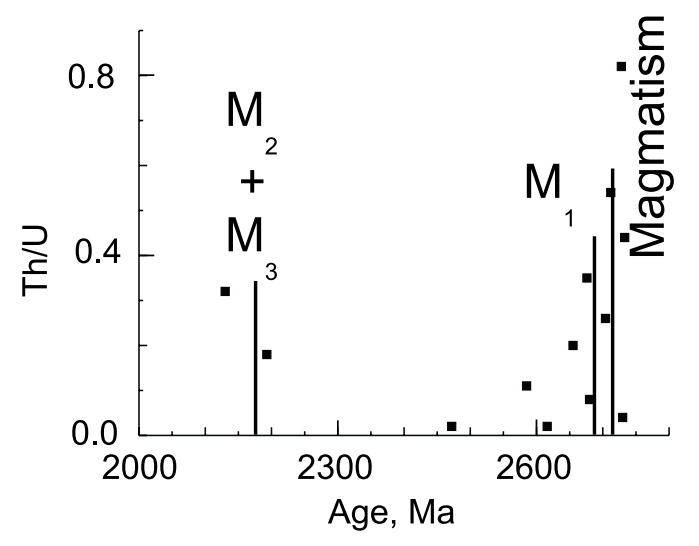

Fig. 4-Age $\times$ Th/U diagram of zircons, sample AL-1, showing a decrease in $\mathrm{Th} / \mathrm{U}$ ratio from the magmatic ( $\sim 0.4)$ to the metamorphic $(\sim 0.02)$ compositions. The 0.3 ratios near 2.1 Ga may be due to variation in fluid composition or physical conditions.

respectively. Zircon analyses were carried out on a Sensitive High Resolution Ion Micro Probe mass spectrometer (SHRIMP II) operated by a consortium consisting of Curtin University of Technology, the Geological Survey of Western Australia and the University of Western Australia with the support of the Australian Research Council. Paul Potter is thanked for his contribution to the manuscript. The authors benefitted from the review of an early version of the manuscript by U. Schaltegger, J. M. Hanchar and R. White.

\section{APPENDIX 1}

\section{SAMPLES}

In the Luís Alves quarry, rocks are exposed in a nearly vertical face of $80 \mathrm{~m}$ length by $40 \mathrm{~m}$ height. Narrow $(\sim 1 \mathrm{~m})$ vertical shear zones cut the subvertical granulites; epidote and chlorite occur in the shear zones and in veinlets. Secondary garnet is present in very small amounts. The rocks are predominately intermediate with less bimodal basicacid rocks present. The basic rocks occur mostly as small (0.5-1.0 m) remnant blocks. The basic rocks mixed tectonically with the enclosing acid rocks many with gradational contacts. Sample AL-1 is a trondhjemitic granulite selected for dating. Sample AL-2 is a mafic gneiss from the quarry. Sample 9 was collected $100 \mathrm{~m}$ north of the quarry; it is a mafic granulite with important simplectitic microstructures.

The trondhjemite, sample AL-1, is medium grained, greenish gray orthogneiss with a diffuse foliation. Simplectites of orthopyroxene, clinopyroxene, plagioclase and hornblende are present between $\mathrm{M}_{1}$ hornblende and $\mathrm{M}_{1}$ plagioclase and locally between orthopyroxenes or clinopyroxenes and plagioclases (Fig. 5). The simplectite minerals show a granoblastic equilibrium texture. The mineral phases were identified by electron microprobe using EDS and then chemically analysed with WDS techniques. The $\mathrm{Al}_{2} \mathrm{O}_{3}$ content of the $\mathrm{M}_{1}$ orthopyroxenes is around $1.3 \mathrm{wt} \%$ and drops to $0.9 \mathrm{wt} \%$ in the simplectitic $\mathrm{M}_{2}$ orthopyroxenes (Table II).

Sample AL-2 has abundant medium-grained hornblende and plagioclase. Clinopyroxene, plagioclase, hornblende and titanite are only present as minute simplectites around hornblende (no orthopyroxene in the simplectites). Sample 9, in contrast, contains abundant orthopyroxene and clinopyroxene, in addition to plagioclase and hornblende in the simplectites; larger hornblende occurs rimming pyroxene crystals. A distinctive microstructure in the mafic granulite, sample 9 (Fig. 6), is the presence of simplectites of orthopyroxene, clinopyroxene, plagioclase and hornblende as rims on hornblende, which crystallized between crystals of pyroxene and plagioclase. The microstructures in three rock samples involving plagioclase and pyroxene are consistent with ductile deformation.

\section{APPENDIX 2 METAMORPHISM}

Magmatic textures are poorly preserved in the granulites (Fornari 1998), although strongly exsolved porphyroclasts of orthopyroxene, clinopyroxene and plagioclase are a strong indication that the highgrade deformation did not entirely erase the magmatic memory of the gneisses. The thermal event ac- 

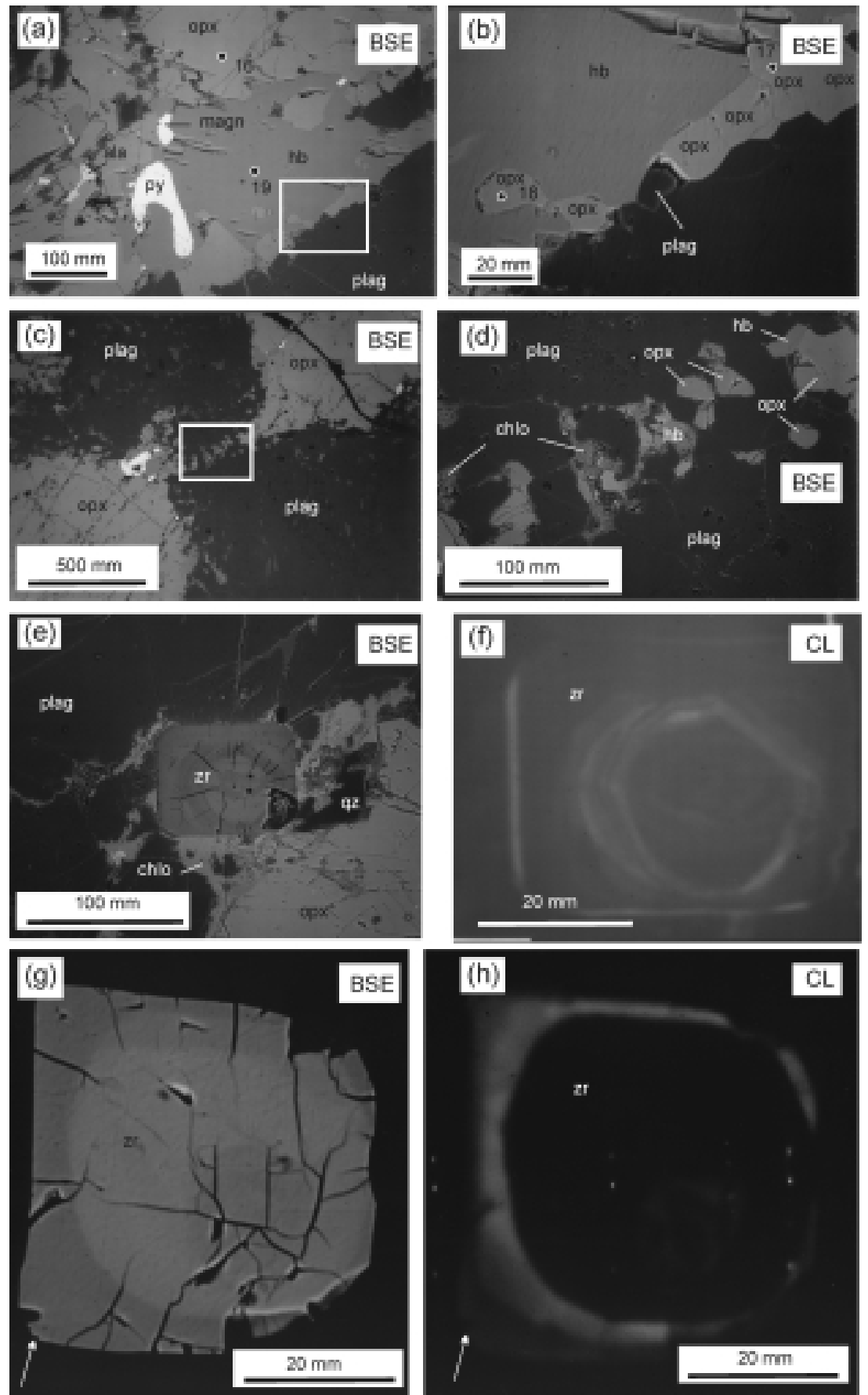

Fig. 5 - Backscattered electrons (BSE) and cathodoluminescence (CL) images from a thin section of the dated sample AL-1. All minerals were identified by electron microprobe. (a)-(d) Numbered spots are locations of chemical analyses by electron microprobe (Table I). Metamorphic $M_{1}$ orthopyroxene (large crystals) shown; $M_{3}$ orthopyroxene crystals in symplectites also shown. (e) Zircon crystal in intercrystalline position, surrounded in part by chlorite. Zircon has euhedral to subhedral form and some rounding due to metamorphism. (f) Same zircon crystal as Figure (e). Marked diffusional replacement of cores in the two crystals of (e)-(h) and also of rim in (h). Remnant (unsealed) radial fractures seen in preserved magmatic mantle in (e). Arrows in (g) and (h) in same relative position with respect to the crystal rim. 


\section{TABLE II}

Chemical analyses by electron microprobe of minerals from Santa Catarina granulite, sample AL-1.

\begin{tabular}{|c|c|c|c|c|c|c|c|c|c|}
\hline $\begin{array}{l}\text { Analysis } \\
\text { Mineral } \\
\text { Event }\end{array}$ & $\begin{array}{c}1 \\
\text { opx } \\
\mathrm{M}_{1}\end{array}$ & $\begin{array}{c}2 \\
\operatorname{cpx} \\
\mathrm{M}_{1}\end{array}$ & $\begin{array}{c}4 \\
\text { opx } \\
\mathrm{M}_{3}\end{array}$ & $\begin{array}{c}5 \\
\mathrm{cpx} \\
\mathrm{M}_{3}\end{array}$ & $\begin{array}{c}6 \\
\text { opx } \\
\mathrm{M}_{3}\end{array}$ & $\begin{array}{c}7 \\
\mathrm{cpx} \\
\mathrm{M}_{3}\end{array}$ & $\begin{array}{c}8 \\
\text { opx } \\
\mathrm{M}_{3}\end{array}$ & $\begin{array}{c}9 \\
\mathrm{cpx} \\
\mathrm{M}_{3}\end{array}$ & $\begin{array}{c}10 \\
\text { opx } \\
\mathrm{M}_{1}\end{array}$ \\
\hline $\mathrm{SiO}_{2}$ & 50.30 & 51.74 & 50.50 & 52.1 & 50.30 & 52.30 & 51.30 & 52.63 & 50.72 \\
\hline $\mathrm{TiO}_{2}$ & 0.11 & 0.19 & 0.06 & 0.03 & 0.11 & 0.19 & 0.07 & 0.14 & 0.00 \\
\hline $\mathrm{Al}_{2} \mathrm{O}_{3}$ & 1.13 & 1.98 & 0.99 & 1.8 & 0.98 & 1.83 & 0.93 & 1.85 & 1.11 \\
\hline $\mathrm{FeO}$ & 32.60 & 13.06 & 32.20 & 11.40 & 32.60 & 11.20 & 31.80 & 12.45 & 32.72 \\
\hline $\mathrm{Fe}_{2} \mathrm{O}_{3}$ & 0.74 & 0.00 & 0.00 & 1.14 & 0.00 & 0.47 & 0.00 & 0.00 & 0.63 \\
\hline $\mathrm{MnO}$ & 0.82 & 0.29 & 0.86 & 0.29 & 0.78 & 0.32 & 0.81 & 0.37 & 0.83 \\
\hline $\mathrm{MgO}$ & 14.60 & 10.91 & 14.90 & 11.5 & 14.7 & 11.4 & 14.9 & 11.41 & 14.85 \\
\hline $\mathrm{CaO}$ & 0.62 & 20.96 & 0.38 & 22.1 & 0.45 & 22.26 & 0.47 & 21.62 & 0.48 \\
\hline $\mathrm{Na}_{2} \mathrm{O}$ & 0.00 & 0.35 & 0.00 & 0.35 & 0.00 & 0.48 & 0.00 & 0.34 & 0.00 \\
\hline Total & 101.00 & 99.48 & 99.90 & 101.00 & 99.90 & 100.5 & 100.00 & 100.80 & 101.30 \\
\hline Analysis & 11 & 12 & 13 & 14 & 15 & 16 & 17 & 18 & 19 \\
\hline Mineral & $\operatorname{cpx}$ & opx & $\operatorname{cpx}$ & opx & $\operatorname{cpx}$ & opx & opx & opx & $\mathrm{hb}$ \\
\hline Event & $\mathrm{M}_{1}$ & $\mathrm{M}_{3}$ & $\mathrm{M}_{3}$ & $\mathrm{M}_{3}$ & $\mathrm{M}_{3}$ & $\mathrm{M}_{1}$ & $\mathrm{M}_{3}$ & $\mathrm{M}_{3}$ & $\mathrm{M}_{2}$ \\
\hline $\mathrm{SiO}_{2}$ & 51.82 & 49.92 & 52.30 & 50.00 & 51.66 & 51.55 & 51.79 & 51.42 & 41.7 \\
\hline $\mathrm{TiO}_{2}$ & 0.28 & 0.12 & 0.17 & 0.03 & 0.20 & 0.05 & 0.00 & 0.19 & 1.09 \\
\hline $\mathrm{Al}_{2} \mathrm{O}_{3}$ & 2.06 & 0.91 & 1.58 & 0.92 & 1.73 & 0.92 & 0.68 & 1.04 & 12.40 \\
\hline $\mathrm{FeO}$ & 14.06 & 32.23 & 11.17 & 33.2 & 12.47 & 29.16 & 29.13 & 28.68 & 17.50 \\
\hline $\mathrm{Fe}_{2} \mathrm{O}_{3}$ & 0.42 & 0.00 & 0.00 & 0.05 & 0.13 & 0.18 & 0.00 & 0.00 & 0.00 \\
\hline $\mathrm{MnO}$ & 0.35 & 0.83 & 0.27 & 0.77 & 0.31 & 0.71 & 0.69 & 0.67 & 0.10 \\
\hline $\mathrm{MgO}$ & 10.82 & 14.41 & 11.41 & 14.2 & 11.05 & 17.55 & 17.58 & 17.37 & 9.99 \\
\hline $\mathrm{CaO}$ & 20.51 & 0.38 & 22.39 & 0.46 & 21.17 & 0.41 & 0.31 & 0.29 & 11.5 \\
\hline $\mathrm{Na}_{2} \mathrm{O}$ & 0.46 & 0.00 & 0.33 & 0.00 & 0.49 & 0.00 & 0.00 & 0.00 & 0.10 \\
\hline Total & 100.80 & 98.83 & 99.64 & 99.60 & 99.24 & 100.60 & 100.30 & 99.72 & 97.60 \\
\hline
\end{tabular}

Note: Content $0.00=$ below detection limit

companying deformation - metamorphic event $\mathrm{M}_{1}$, was in the granulite facies, as shown by the volumetrically dominant association of two pyroxenes in mafic lithologies and by the widespread occurrence of orthopyroxenes in the acid lithologies. Orthopyroxene is well crystallized in quartzites and iron formations, which is typical of $\mathrm{M}_{1}$ crystals; $\mathrm{M}_{3}$ orthopyroxenes were only observed in fine grained symplectites around hornblende.

The temperature of $\mathrm{M}_{1}$ metamorphic event is estimated about $800^{\circ} \mathrm{C}$ based on two-pyroxene thermometry (Girardi \& Ulbrich 1980, Hartmann 1988, Basei et al. 1998, Fornari 1998). Pressure during $\mathrm{M}_{1}$ was estimated at $\sim 6 \mathrm{~kb}$ by Girardi and Ulbrich (1980), an estimate consistent with the lack of garnet formed in the mafic granulites in the $\mathrm{M}_{1}$ event.

Because hornblende mantles the $\mathrm{M}_{1}$ orthopyroxene and clinopyroxene, a $\mathrm{M}_{2}$ metamorphic event in the amphibolite facies can be presumed, possi- bly occurring while temperature decreased. The $\mathrm{M}_{2}$ hornblende has $\mathrm{TiO}_{2}$ contents around $2.2 \mathrm{wt} \%$. The remarkable simplectitic texture of two pyroxenes plus plagioclase and hornblende indicates metamorphic conditions in the granulite facies during a $\mathrm{M}_{3}$ metamophic event, presumably during increasing temperature after the formation of the hornblendes or more extensive dehydration of the rocks. Temperatures are estimated at $800 \pm 50^{\circ} \mathrm{C}$ for the $\mathrm{M}_{3}$ event, based on two-pyroxene thermometry (Brey \& Kohler 1990); data used are chemical analyses of two pyroxenes by electron microprobe.

Granulite facies simplectites are uncommon (e.g. Passchier \& Trouw 1996), but Schenk (1984, PLATE 5B) presents several types of symplectites, mostly garnet-bearing, but also orthopyroxe, plagioclase and ilmenite bearing coronas around hornblende. Harley (1988) describes the decompression formation of symplectites of orthopyroxene + 

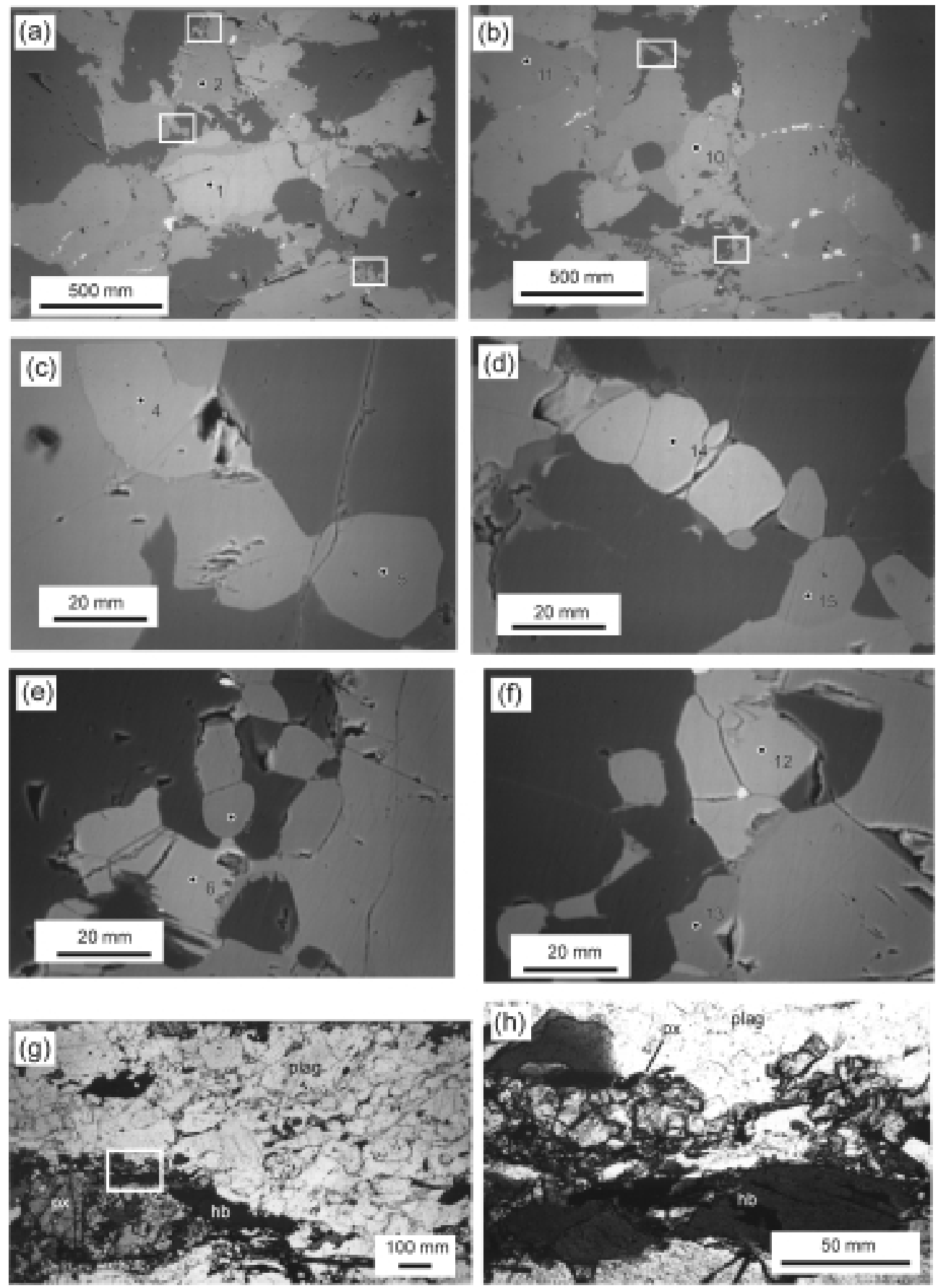

Fig. 6-Sample 9, mafic granulite. BSE images in (a)-(f) and microphotographs in (g)-(h). Granoblastic texture of orthopyroxene, clinopyroxene and plagioclase, rimmed by hornblende, which in turn is rimmed by granoblastic simplectites of orthopyroxene + clinopyroxene + plagioclase + hornblende. All minerals were identified by electron microprobe. Numbered spots are chemical analyses by electron microprobe (Table I). 
plagioclase between garnet and clinopyroxene and around hornblende. Messiga and Bettini (1990) make a general observation about a plagioclase, orthopyroxene and clinopyroxene bearing corona around garnet, and they also describe coronas of orthopyroxene and orthopyroxene + plagioclase, and finegrained kelyphite of elongated grains of orthopyroxene + spinel + plagioclase \pm amphibole. Baba (1998) describes the formation of orthopyroxene + plagioclase around garnet by isothermal decompresion in the Lewisian complex.

The following sequence of events is recognized in the dated granulite quarry and is also based on extensive observations in the Santa Catarina granulite complex in the Luís Alves region,

1. Magmatism (island arc) - Strongly exsolved porphyroclasts of orthopyroxene + clinopyroxene + plagioclase;

2. Granulite facies $\mathbf{M}_{1}$ (middle crust, subvertical banding) - Granoblastic orthopyroxene + clinopyroxene + plagioclase $\left(\mathrm{An}_{35-65}\right)$;

3. Amphibolite facies $\mathrm{M}_{2}$ (middle crust) - Hornblende $\left(2.2 \mathrm{wt} \% \mathrm{TiO}_{2}\right)+$ plagioclase

4. Granulite facies $\mathrm{M}_{3}$ (middle crust, mylonitic) - Simplectitic orthopyroxene + clinopyroxene + plagioclase + hornblende $\left(0.15 \mathrm{wt} \% \mathrm{TiO}_{2}\right)$;

5. Greenschist facies $\mathrm{M}_{4}$ (upper crust, cataclastic) - Epidote + chlorite + quartz.

Quartz and accessory biotite are present in most mafic and acid granulite samples. The absence of garnet in mafic granulites is an indication that the complex never attained lower crustal conditions.

The U/Pb SHRIMP isotopic results and interpretation of ages reflect the superposition of high temperature events in the zircon crystals. The P-T path may be of isothermal decompression, but the absence of garnet in the mafic lithologies during $\mathbf{M}_{1}$ requires additional investigations, because the variation of pressure seems to have occurred outside of the garnet stability field.

\section{REFERENCES}

Almeida FFM DE \& Hasui Y. 1984. O Pré-Cambriano do Brasil. Edgard Blücher Editors, Porto Alegre, Brazil.

BabA S. 1998. Proterozoic anticlockwise P-T path of the Lewisian Complex of South Harris, Outer Hebrides, NW Scotland. Jour Met Geol 16: 819-841.

BARrie CT \& Krogh TE. 1996. U-Pb zircon geochronology of the Selbaie $\mathrm{Cu}-\mathrm{Pb}$ zircon geochronology of the Selbaie $\mathrm{Cu}-\mathrm{Zn}-\mathrm{Ag}-\mathrm{Au}$ Mine, Abitibi Subprovince, Canada. Econ Geol 91: 563-575.

Basei MAS, McReath I \& Siga JR O. 1998. The Santa Catarina granulite complex of southern Brazil: a review. Gondwana Res 1: 373-381.

Brey GP \& Kohler T. 1990. Geothermobarometry in four-phase lherzolites. II. New thermobarometers, and practical assessment of existing thermobarometers. Jour Petrol 31: 1353-1378.

Campos Neto MC \& Caby R. 1999. Neoproterozoic high-pressure metamorphism and tectonic constraint from the nappe system south of the São Francisco Craton, southeast Brazil. Prec Res 97: 3-26.

Compston W, Williams IS, Kirschvink JL, ZichaO ZH \& GuOGan M. 1992. Zircon ages for the Early Cambrian time-scale. Jour Geol Soc London 149: 171-184.

CoRFu FC. 1987. Inverse age stratification of the Archean crust of the Superior Province: Evidence for infraand subcrustal accretion from high resolution $\mathrm{U}-\mathrm{Pb}$ zircon and monazite ages. Prec Res 36: 259-275.

De Laeter Jr \& Kennedy AK. 1998. A double focusing mass spectrometer for geochronology. Intern Jour Mass Spectr 178: 43-50.

Figueiredo MCH, McReath I, Basei MAS \& MantoVANI MSM. 1996. Geochemistry of Santa Catarina granulite rocks, southern Brazil: A model of differentiation from high alumina basalt. Rev Bras Geoc 27: $33-40$.

FornARI A. 1998. Geologia e metalogênese da porção meridional do Cráton Luís Alves - SC. Campinas, Brazil. (Unpubl. PhD thesis, Universidade Estadual de São Paulo). 
FRIEND CRL \& KINNY PD. 1995. New evidence for protolith ages of Lewisian granulites, northwest Scotland. Geology 23(11): 1027-1030.

GIRARDI VAV \& Ulbrich HHGJ. 1980. Origin and evolution of the Piên Mafic-ultramafic Complex, southern Brazil. Jour Geol 88: 251-269.

Gresse PG, Chemale F, Silva LC da, Walraven F \& Hartmann LA. 1996. Late- to post-orogenic basins of the Pan-African-Brasiliano collision orogen in southern Africa and southern Brazil. Basin Res 8: 157-171.

Hanchar JM \& Miller CF. 1993. Zircon zonation patterns as revealed by cathodoluminescence and backscattered electron images: Implications for interpretation of complex crustal histories. Chem Geol 110: $1-13$.

Harley SL. 1988. Proterozoic granulites from the Rauer Group, East Antarctica. I. Decompressional pressure-temperature paths deduced from mafic and felsic gneisses. Jour Petrol 29(5): 1059-1095.

Hartmann LA. 1988. Geoquímica de terras raras e geotermobarometria de granulitos de Dom Pedrito e Luís Alves, no extremo sul do Brasil. Geoch Bras 2: $1-14$.

Hartmann LA. 1998. Deepest exposed crust of Brazil - geochemistry of Palaeoproterozoic depleted Santa Maria Chico granulites. Gondwana Res 1: 331-341.

Hartmann LA, Cupertino JA \& NARdi LVS. 1979a. A cataclase nos granulitos de Luís Alves (SC). Acta Geol Leop 6: 29-44.

Hartmann LA, Silva LC DA \& Orlandi V. 1979b. O Complexo Granulítico de Santa Catarina; descrição e implicações genéticas. Acta Geol Leop 6: 93-112.

Hartmann LA, Takehara L, Leite JAD, MCNAughton NJ \& VASCONCEllos MAZ. 1997. Fracture sealing in zircon as evaluated by electron microprobe analyses, back-scattered electrons and cathodoluminescence images. Chem Geol 141: 6772 .

Hartmann LA, Leite JAD, McNaughton NJ \& SANTOS JOS. 1999a. Deepest exposed crust of BrazilSHRIMP establishes three events. Geology 27(10):
$947-950$

Hartmann LA, Basei MAS \& Simas MW. 1999b. Geochemistry of the Lower Proterozoic granulite-facies Grant syenite gneiss, Barra Velha, Santa Catarina State, southern Brazil. Pesquisas 25: 3-9.

Hartmann LA, Leite JAD, Silva LC DA, Remus MVD, McNaughton NJ, Groves DI, Fletcher IR, SANTOS JOS \& VASCONCELlos MAZ. 2000. Advances in SHRIMP geochronology and their impact on understanding the tectonic and metallogenic evolution of southern Brazil. Australian Jour Earth Sci (in press).

Heaman LM \& Parrish R. 1991. U-Pb geochronology of accessory minerals. In: L. HEAMAN \& J. N. LUDDEN ed. Applications of radiogenic isotope systems to problems in geology. Min Assoc Canada Short Course Handbook 19: 59-102.

Iyer SS, Choudhuri A \& Cordani U. 1987. Granulite facies rocks of Brazil: a review of their geologic setting, geochronological evolution, petrographic and geochemical characteristics. Geol Soc India Jour 29: 309-326.

Kaul PFT \& Teixeira W. 1982. Archean and early proterozoic complexes of Santa Catarina, Paraná and São Paulo states, south-southeastern Brazil: an outline of their geological evolution. Rev Bras Geoc 12: 172-182.

Messiga B \& Bettini E. 1990. Reactions behaviour during kelyphite and symplectite formation: a case study of mafic granulites and eclogites from the Bohemian Massif. Eur Jour Mineral 2(1): 125-144.

Moreira MLO \& Marimon MP. 1980. Ensaio petrográfico e petroquímico das rochas da fácies granulito, Complexo Granulítico de Santa Catarina, Folha SB.22-ZB. In: Congresso Brasileiro de GeoloGIA, 33., Camboriú. Proceedings..., Camboriú, Sociedade Brasileira de Geologia, 1980. p. 2119-2133.

PAsschier CW \& Trouw RAJ. 1996. Microtectonics. Springer-Verlag, Berlin.

Remus MVD, McNaughton NJ, Hartmann LA, Koppe JC, Fletcher IR, Groves DI \& Pinto VM. 1999. Gold in the Neoproterozoic juvenile Bossoroca volcanic arc of southernmost Brazil: isotopic constraints on timing and sources. Jour S Amer Earth 
Sci 12: $349-366$

Remus MVD, Hartmann LA, McNaughton NJ, Groves DI \& Fletcehr IR. 2000a. The link between hydrothermal epigenetic copper mineralization and the Caçapava Granite of the Brasiliano Cycle in southern Brazil. Jour S Am Earth Sci (in press).

Remus MVD, Hartmann LA, McNaughton NJ, Groves DI \& ReISCHL JL. 2000b. A distal magmatic hydrothermal origin for the Camaquã $\mathrm{Cu}(\mathrm{Au}-\mathrm{Ag})$ and Santa Maria $\mathrm{Pb}, \mathrm{Zn}(\mathrm{Cu}-\mathrm{Ag})$ deposits, southern Brazil. Gondwana Res 3(2): 155-174.

Rubatto D, Gebauer D \& Fanning M. 1998. Jurassic formation and Eocene subduction of the ZermattSaas-Fee ophiolites: implications for the geodynamic evolution of the Central and Western Alps. Contrib Mineral Petrol 132: 269-287.

SchenK V. 1984. Petrology of felsic granulites, metapelites, metabasics, ultramafics, and metacarbonates from southern Calabria (Italy): Prograde metamorphism, uplift and cooling of a former lower crust. Jour Petrol 25(1): 255-298.

Silva LC DA. 1987. Geologia do Pré-Cambriano/ Eopaleozóico de Santa Catarina. In: L.C. DA SiLva \& C.A. Bortoluzzi. Texto explicativo para o mapa geológico de Santa Catarina 1:500,000. DNPM/ SCTME, Florianópolis, Santa Catarina, Brazil, p. 11-90.
Silva LC DA, Hartmann LA, McNaughton NJ \& FLETCHER IR. 1999. SHRIMP U/Pb zircon timing of Neoproterozoic granitic magmatism and collision in the Pelotas batholith, southernmost Brazil. Internat Geol Rev 41(6): 531-551.

Silva lC DA, Hartmann LA, McNaughton NJ \& FleTCHER IR. 2000. Zircon U-Pb SHRIMP dating of a Neoproterozoic overprint in Paleoproterozoic granitic gneisses, southern Brazil. Am Mineral 85(5-6): 649-667.

Smith JB, Barley ME, Groves DI, Krapez B, MCNaughton NJ, Bickle MJ \& Chapman HJ. 1998. The Scholl shear zone, West Pilbara: Evidence for a terrane boundary structure from integrated tectonic analyses, SHRIMP U/Pb dating and isotopic and geochemical data of granitoids. Prec Res 88: 143-171.

Vavra G, Schmid R \& Gebauer D. 1999. Internal morphology, habit and U-Th-Pb microanalysis of amphibolite-to-granulite facies zircons: geochronology of the Ivrea Zone (Southern Alps). Contrib Mineral Petrol 134: 380-404.

Wernick E \& Almeida FFM DE. 1979. The geotectonic environments of Early Precambrian granulites in Brazil. Prec Res 8: 1-17. 